\title{
OPEN
}

\section{Author Correction: Direct evidence of Neanderthal fibre technology and its cognitive and behavioral implications}

\author{
B. L. Hardy, M.-H. Moncel, C. Kerfant, M. Lebon, L. Bellot-Gurlet \& N. Mélard \\ Correction to: Scientific Reports https://doi.org/10.1038/s41598-020-61839-w, published online 09 April 2020
}

This Article contains errors in Reference 46 which was incorrectly given as:

Sykes, R. W. In Settlement, Society and Cognition in Human Evolution (eds. Coward, F., Hosfield, R., Pope, M. \& Wenban-Smith, F.) 117-137 (Cambridge, Cambridge Univ. Press, 2015).

The correct reference is listed below as ref. 1 :

\section{Reference}

1. Wragg Sykes, R. In Settlement, Society and Cognition in Human Evolution (eds. Coward, F., Hosfield, R., Pope, M. \& Wenban-Smith, F.) 117-137 (Cambridge, Cambridge Univ. Press, 2015).

(c) Open Access This article is licensed under a Creative Commons Attribution 4.0 International (c) License, which permits use, sharing, adaptation, distribution and reproduction in any medium or format, as long as you give appropriate credit to the original author(s) and the source, provide a link to the Creative Commons license, and indicate if changes were made. The images or other third party material in this article are included in the article's Creative Commons license, unless indicated otherwise in a credit line to the material. If material is not included in the article's Creative Commons license and your intended use is not permitted by statutory regulation or exceeds the permitted use, you will need to obtain permission directly from the copyright holder. To view a copy of this license, visit http://creativecommons.org/licenses/by/4.0/.

(C) The Author(s) 2020 